\title{
ANALISIS STRATEGI PENGEMBANGAN PARIWISATA DI MICE KOTA BATAM
}

\author{
Antonius Rizki Krisnadi ${ }^{1)}$, Yudhiet Fajar Dewantara ${ }^{2)}$ \\ 1)Universitas Bunda Mulia \\ 2) Universitas Bunda Mulia
}

\begin{abstract}
ABSTRAK
Kegiatan Industri MICE di kota Batam tergolong sebagai industri baru masa kini yang menunjukan bahwa MICE sebagi salah satu sektor dalam bisnis pariwisata, karena kegiatan/aktifitas di Batam merupakan kegiatan para pebisnis mengingat Batam adalah kawasan bebas/ free trade zone. Kegiatan bisnis wisata yang tujuan utama dari para delegasi atau peserta kegiatan MICE adalah melakukan perjalanan dan menghadiri suatu kegiatan atau event yang berhubungan dengan bisnisnya sambil menikmati kegiatan wisata secara bersama-sama.

Untuk dapat mengoptimalkan potensi wisata MICE di Batam, diperlukan pengembangan pariwisata yang spesifik pada pengembangan aktivitas. Kajian pengembangan pariwisata MICE yang dilakukan merupakan identifikasi sumber daya sector pariwisata, yang akan menjadi acuan untuk program pembangunan pengembangan pariwisata MICE yang lebih operasional dimana meliputi identifikasi terhadap system kepariwisataan, destinasipariwisata, dampak pariwisata, serta pengembangan terhadap perkembangan kepariwisataan di Kawasan Batamdan Sekitarnya. Penelitian ini dianalisis menggunakan SWOT.

Skor dari Matrik IFAS Wisata MICE Batam diperoleh dari hasil rata-rata pembobotan masing-masing indikator internal yang dikalikan dengan hasil rata-rata rating masing-masing indikator internal, maka didapatlah skor untuk masing-masing indikator internal. Setelah itu skor dari seluruh indikator-indikator internal harus dijumlahkan dengan cara menjumlahkan skor dari indikator pertama sampai dengan indikator terakhir untuk memperoleh hasil skor lingkungan internal. Hasil skor dari matrik IFAS pada adalah 2.65.

Skor dari matrik EFAS wisata MICE Batam diperoleh dari hasil rata-rata pembobotan masing-masing indikator eksternal yang dikalikan dengan hasil rata-rata rating masing-masing indikator eksternal, maka didapatlah skor untuk masing-masing indikator eksternal. Setelah itu skor dari seluruh indikator-indikator eksternal harus dijumlahkan dengan cara menjumlahkan skor dari indikator pertama sampai dengan indikator terakhir untuk memperoleh hasil skor lingkungan eksternal. Hasil skor dari matrik EFAS adalah 2.85.
\end{abstract}

Kata Kunci : MICE, Pengembangan, Wisata, SWOT

\begin{abstract}
MICE Industry Activities in Batam city is classified as a new industry that shows MICE as one of the sectors in tourism business, because activity / activity in Batam is business activity considering Batam is free trade zone. Business tourism activities that are the main purpose of the delegates or participants of MICE activities are to travel and attend an event or event related to the business while enjoying tourism activities together.

To be able to optimize the potential of MICE tourism in Batam, it is necessary to develop a specific tourism development activity. The MICE tourism development study is an identification of tourism sector resources, which will become a reference for the development of a more operational MICE tourism development program which includes identification of tourism systems, tourism destinations, tourism impacts, and development of tourism development in Batam and surrounding areas. This study was analyzed using SWOT.

Scores of IFAS Matrix MICE Batam Tourism is derived from the weighted average of each internal indicator multiplied by the average rating of each internal indicator, then scores for each internal indicator are obtained. Thereafter the score of all internal indicators should be summed by summing the scores from the first indicator to the last indicator to obtain an internal environmental score result. The score of the IFAS matrix on is 2.65.

Scores of the MICE Batam EFAS matrix are derived from the weighted average of each external indicator multiplied by the average rating of each external indicator, then scores for each external indicator are obtained. Thereafter the score of all external indicators should be summed by summing the scores from the first indicator to the last indicator to obtain the external environmental score results. The score of the EFAS matrix is 2.85.
\end{abstract}

Keywords: MICE, Development, Tour, SWOT 


\section{PENDAHULUAN}

Istilah MICE di Indonesia dikenal juga dengan nama wisata konvensi, kegiatan wisata konvensi ini merupakan bagian dari kegiatan pariwisata, karena banyak sekali menggunakana fasilitas pariwisata dalam pelaksanaannya, sehingga kegiatan ini merupakan kegiatan yang berkarakteristik padat karya, memberikan kontribusi baik dari sisi penyediaan tenagakerja maupun dalam memberikan devisa Negara.

Kegiatan Industri MICE di kota Batam tergolong sebagai industry baru masa kini yang menunjukan bahwa MICE sebagi salah satu sektor dalam bisnis pariwisata, karena kegiatan/aktifitas di Batam merupakan kegiatan para pebisnis mengingat Batam adalah kawasan bebas/ free trade zone. Kegiatan bisnis wisata yang tujuan utama dari para delegasi atau peserta kegiatan MICE adalah melakukan perjalanan dan menghadiri suatu kegiatan atau event yang berhubungan dengan bisnisnya sambil menikmati kegiatan wisata secara bersama-sama.

Penunjukan Batam sebagai kota MICE akan memberikan pengaruh bagi perkembangan perekonomian. Disamping itu, industri MICE bertujuan untuk meningkatkan citra Indonesia sebagai tujuan pariwisata yang aman, kerja sama antar daerah dan negara, memacu investasi, serta membuka lapangan kerja dan peningkatan devisa serta Produk Domestik Bruto (PDB). Adapun keunggulan industri MICE antara lain adalah mendatangkan wisatawan dalam jumlah besar, lama tinggal (length of stay) lebih lama, dampak promosi yang luar, jumlah uang yang dibelanjakan, peningkatan infrastruktur, serta memberikan kebanggaan dan memperkuat diplomasi bangsa.

Korespondensi Penulis:

Antonius Rizki Krisnadi akrisnadi@bundamulia.ac.id

\section{URGENSI PENELITIAN}

Kajian pengembangan pariwisata MICE yang dilakukan merupakan identifikasi sumber daya sektor pariwisata, yang akan menjadi acuan untuk program pembangunan pengembangan pariwisata MICE yang lebih operasional dimana meliputi identifikasi terhadap sistem kepariwisataan, destinasi pariwisata, dampak pariwisata, serta pengembangan terhadap perkembangan kepariwisataan di Kawasan Batam dan Sekitarnya.

\section{TINJAUAN PUSTAKA}

Meeting Incentive Conference Exhibition ( MICE) sebagai sebuah destinasi pariwisata.

Sedangkan menurut Kesrul (2004:3), MICE sebagai suatu kegiatan kepariwisataan yang aktifitasnya merupakan perpaduan antara leisure dan business, biasanya melibatkan sekelompok orang secara bersama-sama, rangkaian kegiatannya dalam bentuk meetings, incentive travels, conventions, congresses, conference dan exhibition.Bentuk wisata MICE adalah :

\section{A. Meeting}

Menurut Kesrul (2004:8), Meeting Suatu pertemuan atau persidangan yang diselenggarakan oleh kelompok orang yang tergabung dalam asosiasi, perkumpulan atau perserikatan dengan tujuan mengembangkan profesionalisme, peningkatan sumber daya manusia, menggalang kerja sama anggota dan pengurus, menyebarluaskan informasi terbaru, publikasi, hubungan kemasyarakatan.

\section{B. Incentive}

Menurut Kesrul (2004:18), bahwa insentive merupakan hadiah atau penghargaan yang diberikan oleh suatu perusahaan kepada 
karyawan, klien, atau konsumen. Bentuknya bisa berupa uang, paket wisata atau barang.

\section{Conference}

Menurut Kesrul, (2004 :7), Conference atau konferensi adalah suatu pertemuan yang diselenggarakan terutama mengenai bentukbentuk tata karena, adat atau kebiasaan yang berdasarkan mufakat umum, dua perjanjian antara negara-negara para penguasa pemerintahan atau perjanjian international mengenai topik tawanan perang dan sebagainya.

\section{Exhibition}

Menurut Kesrul (2004:16), exhibition adalah ajang pertemuan yang dihadiri secara bersamasama yang diadakan di suatu ruang pertemuan atau ruang pameran hotel, dimana sekelompok produsen atau pembeli lainnya dalam suatu pameran dengan segmentasi pasar yang berbeda.

\section{SWOT}

Dalam rangka mewujudkan Batam menjadi destinasi wisata MICE perlu dianalisis mengenai strategi pengembangannya. Menurut Kurtz $(2008,45)$, SWOT analisis adalah suatu alat perencanaan strategik yang penting untuk membantu perencana untuk membandingkan kekuatan dan kelemahan internal organisasi dengan kesempatan dan ancaman dari external. Menurut Robert W.Duncan (2007, 142), menganalisa lingkungan internal dan eksternal merupakan hal penting dalam proses perencanaan strategi. Faktor-faktor lingkungan internal di dalam perusahaan biasanya dapat digolongkan sebagai Strength (S) atau Weakness (W), dan lingkungan eksternal perusahaan dapat diklasifikasikan sebagai Opportunities (O) atau Threat (T). Analisis lingkungan strategi ini disebut sebagai analisis SWOT.

\section{Desain Penelitian}

Penelitian ini mempunyai keluaran untuk membuat alternatif strategi bagi wisata MICE
Batam. Alternatif strategi tersebut dibuat berdasarkan analisis SWOT. Dalam analisis SWOT, terdapat analisis lingkungan internal dan eksternal.

Lingkungan eksternal kepariwisataan yang selalu bersifat dinamis memberikan implikasi terhadap kompleksitas pengorganisasian kegiatan kepariwisataan Batam, khususnya Wisata MICE.Oleh karenanya, tingkat pemahaman terhadap isu-isu pokok saat ini dan masa depan akan sangat mempengaruhi keberhasilan pembangunan kepariwisataan. Strategi perusahaan yang disusun perlu diselaraskan dengan kecenderungan dan isu-isu strategis tersebut.

Salah satu komponen dalam memahami isu - isu pokok adalah pencermatan terhadap lingkungan eksternal Wisata MICE mengandung arti suatu tindakan scanning peluang dan tantangan yang ada, yang terdiri dari dua aspek utama yaitu :

1. Aspek Lingkungan Mikro (task environment), yaitu aspek yang secara langsung berinteraksi dan mempengaruhi kegiatan Wisata MICE.

Yang termasuk aspek ini adalah aspek pasar, keamanan dan lokasi MICE.

2. Aspek Lingkungan Makro (societal environment), yaitu aspek eksternal makro yang turut mempengaruhi Wisata MICE.

Yang termasuk aspek ini antara lain ekonomi dan bisnis, sosial budaya, lingkungan, dan teknologi.

Sementara itu, dalam kajian pencermatan lingkungan internal ini pembahasan akan ditekankan kepada tiga aspek utama yang berimplikasi langsung terhadap dinamika kondisi lingkungan internal seperti yang dikemukakan oleh Kotler dan Amstrong (1997) dan Zeinthaml and Bitner (2006) yang mengungkapkan lingkungan internal perusahaan untuk kebijakan strategis secara umum adalah product, price, place dan promotion (Kotler and Amstrong, 1997) ditambah dengan people, 
process and phisical evidence (Zeithaml dan Bitner, 2006)

Kajian pencermatan lingkungan internal ini merupakan pembahasan kekuatan dan kelemahan yang akan menjadi bahan acuan dalam perumusan kebijakan dan strategi pengembangan Wisata MICE Batam, Kepulauan Riau.

Penelitian ini menggunakan metode kuantitatif dengan menggunakan kuesioner dan daftar periksa sebagai alat kumpul data. Daftar periksa tersebut dibagikan kepada level managerial di Dinas Pariwisata Kota Batam, sementara itu kuesioner dibagikan kepada pengunjung.

\section{TUJUAN DAN MANFAAT PENELITIAN}

Tujuan penelitian pada kali ini adalah mengkaj imengenai :

a. Identifikasi lingkungan eksternal wisata MICE Batam

b. Identifikasi lingkungan internal wisata MICE Batam

c. Pilihan strategi dalam mengembangkan wisata MICE Batam

Manfaat penelitian pada kali ini adalah :

a. Mengetahui kondisi aktual lingkungan eksternal wisata MICE Batam

b. Mengetahui kondisi aktual lingkungan internal wisata MICE Batam

c. Mengidentifikasi alternatif strategi dalam mengembangkan wisata MICE Batam

d. Memperkaya kajian di bidang pengembangan strategi wisata MICE Batam

\section{METODE PENELITIAN}

\section{Teknik Pengolahan Data}

Teknik pengolahan data yang kedua menggunakan analisis SWOT. Analisis SWOT banyak di pergunakan di Indonesia dan mungkin sudah diketahui nilai dan manfaat dari analisis tersebut. Dalam bagian ini akan diulas sedikit mengenai teknik analisis secara teoritis. Analisis pada umumnya digunakan apabila para stakeholder atau pelaku pariwisata MICE dalam membuat keputusan yang bersifat stratejik. Sebagai suatu keputusan yang stratejik maka harus dilakukan analisis yang mendetail tentang objek wisata yang bersangkutan untuk mendapatkan titik temu antara factor-faktor stratejik dalam lingkungan internal dan lingkunganeksternal, sambil menghubungkan tujuan dan sasaran organisasi tersebut.

Perumusan keputusan stratejik yang baik dapat dilakukan melalui konsep SWOT.

\section{Teknik Pengumpulan Data}

Teknik pengumpulan data dilakukan dengan obeservasi, studi literature, studi dokumentasi dan kuesioner.

\section{Matriks SWOT}

Matrik tersebut dapat dijelaskan sebagai berikut

1. Faktor eksternal, yaitu peluang dan ancaman.

2. Faktor internal yaitu kekuatan dan kelemahan.

3. Keunggulankomprehensif yaitu stratejik yang dihadapi oleh tempat wisata MICE menakala terdapat peluang yang memiliki posisi internal yang kuat, hal ini hatempat wisata MICE menakala terdapat peluang yang memiliki posisi internal yang kuat, hal ini harusdimanfaatkansebaikbaiknyarusdimanfaatkansebaik-baiknya.

4. Mobilisasi yaitu pertemuan antara ancaman atau tantangan dari luar dengan kekuatanorganisasi. Dalam hal ini, organisasiharus mampu memobilisasi sumber daya untuk mengatasi ancaman, bahkan bila memungkinkan mengubahnya menjadi peluang.

5. Memilih atau menjatuhkan pilihan, yaitu terdapatnya peluang yang tersedia tetapi tidak ada kemampuan organisasi untuk menggarapnya dan memberikan reaksi positif. 
6. Kerugian, yaitu pertemuan ancaman dan kelemahan yang harus menjadi kan acuan bagi perbaikan-perbaikan dalam menentukan potensi kajian analisis wisata MICE di Batam, Kepualauan Riau.

HASIL DAN LUARAN PENELITIAN
Berikut adalah tabel hasil perpaduan matrik EFAS dan IFAS wisata MICE Kota Batam.

Tabel 3 Matriks Eksternal Faktor

\begin{tabular}{|c|l|c|c|c|}
\hline No. & \multicolumn{1}{|c|}{ Indikator Eksternal } & $\begin{array}{c}\text { Bobot } \\
(\%)\end{array}$ & Rating & Score \\
\hline 1 & Penerapan teknologi informasi & $7.75 \%$ & 2.65 & 0.21 \\
\hline 2 & $\begin{array}{l}\text { Sumber daya manusia yang } \\
\text { professional }\end{array}$ & $7.98 \%$ & 2.70 & 0.22 \\
\hline 3 & Keamanan pengunjung & $7.72 \%$ & 3.25 & 0.25 \\
\hline 4 & $\begin{array}{l}\text { Keamanan lokasi tempat wisata MICE } \\
\text { Batam }\end{array}$ & $7.65 \%$ & 3.30 & 0.25 \\
\hline 5 & Lokasi tempat wisata MICE Batam & $8.17 \%$ & 3.35 & 0.27 \\
\hline 6 & Pemandangan alam sekitar & $7.27 \%$ & 3.15 & 0.23 \\
\hline 7 & $\begin{array}{l}\text { Kebijakan pemerintah di bidang } \\
\text { pariwisata }\end{array}$ & $6.18 \%$ & 2.45 & 0.15 \\
\hline 8 & Bantuan dan dukungan pemerintah & $6.07 \%$ & 2.05 & 0.12 \\
\hline 9 & $\begin{array}{l}\text { Peran serta masyarakat serta } \\
\text { komunitas }\end{array}$ & $6.48 \%$ & 2.05 & 0.13 \\
\hline 10 & $\begin{array}{l}\text { Pengawasan masyarakat terhadap } \\
\text { tempat wisata MICE Batam }\end{array}$ & $6.70 \%$ & 2.60 & 0.17 \\
\hline 11 & Kondisi ekonomi regional dan nasional & $6.41 \%$ & 2.65 & 0.17 \\
\hline 12 & Kondisi ekonomi global & $6.31 \%$ & 2.50 & 0.16 \\
\hline 13 & Variasi profil pengunjung & $7.85 \%$ & 3.45 & 0.27 \\
\hline 14 & Motivasi pengunjung & $7.45 \%$ & 3.30 & 0.25 \\
\hline TOTAL & 100 & 2.85 \\
\hline
\end{tabular}

Table 4. Matriks Internal Faktor 


\begin{tabular}{|l|l|c|c|r|}
\hline No. & \multicolumn{1}{|c|}{ Indikator Internal } & Bobot (\%) & Rating & Score \\
\hline $\mathbf{1}$ & Keanekaragaman kegiatan wisata MICE Batam & $6.90 \%$ & 3.25 & 0.22 \\
\hline $\mathbf{2}$ & Keunikan kegiatan wisata MICE Batam & $6.61 \%$ & 3.05 & 0.20 \\
\hline $\mathbf{3}$ & kondisi pemandangan kamar & $5.91 \%$ & 3.05 & 0.18 \\
\hline $\mathbf{4}$ & Harga tiket masuk kegiatan MICE & $5.96 \%$ & 2.90 & 0.17 \\
\hline $\mathbf{5}$ & Harga fasilitas penunjang & $4.13 \%$ & 2.40 & 0.10 \\
\hline $\mathbf{6}$ & Harga makanan dan minuman & $5.00 \%$ & 2.90 & 0.15 \\
\hline $\mathbf{7}$ & Kemudahan dalam mencapai lokasi & $4.77 \%$ & 2.35 & 0.11 \\
\hline $\mathbf{8}$ & Kejelasan jalur / rute yang dilalui menuju tempat wisata MICE Batam & $5.12 \%$ & 2.30 & 0.12 \\
\hline $\mathbf{9}$ & Penyampaian informasi melalui mass media cetak (brosur, pamflet,dll) & $5.12 \%$ & 2.60 & 0.13 \\
\hline $\mathbf{1 0}$ & Penyampaian informasi melalui website & $5.55 \%$ & 2.70 & 0.15 \\
\hline $\mathbf{1 1}$ & Penyampaian informasi melalui mass media audio visual (iklan) & $3.95 \%$ & 2.50 & 0.10 \\
\hline $\mathbf{1 2}$ & Kemampuan petugas berkomunikasi dalam berbagai bahasa & $5.43 \%$ & 2.35 & 0.13 \\
\hline $\mathbf{1 3}$ & Program pendidikan dan pelatihan bagi petugas & $4.45 \%$ & 1.75 & 0.08 \\
\hline $\mathbf{1 4}$ & Penampilan petugas & $2.44 \%$ & 1.75 & 0.04 \\
\hline $\mathbf{1 5}$ & Keramahtamahan petugas & $2.80 \%$ & 1.75 & 0.05 \\
\hline $\mathbf{1 6}$ & Fasilitas pendukung yang tersedia & $5.50 \%$ & 3.10 & 0.17 \\
\hline $\mathbf{1 7}$ & Sarana dan prasarana yang memadai & $5.60 \%$ & 3.55 & 0.20 \\
\hline $\mathbf{1 8}$ & Rute perjalanan pengunjung & $4.63 \%$ & 1.55 & 0.07 \\
\hline $\mathbf{1 9}$ & Proses penyambutan kedatangan wisatawan & $4.95 \%$ & 2.50 & 0.12 \\
\hline $\mathbf{2 0}$ & Pelayanan yang diberikan & $5.20 \%$ & 3.00 & 0.16 \\
\hline $\mathbf{T O T A L}$ & 100 & & 2.65 \\
\hline & & & \\
\hline
\end{tabular}

Skor dari Matrik IFAS dan EEFAS pada di atas diperoleh dari hasil rata-rata pembobotan masing-masing indikator internal dan eksternal yang dikalikan dengan hasil rata-rata rating masing-masing indikator internal dan eksternal , maka didapatlah skor untuk masing-masing indikator internal dan eksternal . Setelah itu skor dari seluruh indikator-indikator internal dan eksternal harus dijumlahkan dengan cara menjumlahkan skor dari indikator pertama sampai dengan indikator terakhir untuk memperoleh hasil skor lingkungan internal. Hasil skor dari matrik IFAS pada Tabel di atas adalah 2.65 dan EFAS adalah 2.85.

Tabel 5. Matriks Internal - Eksternal

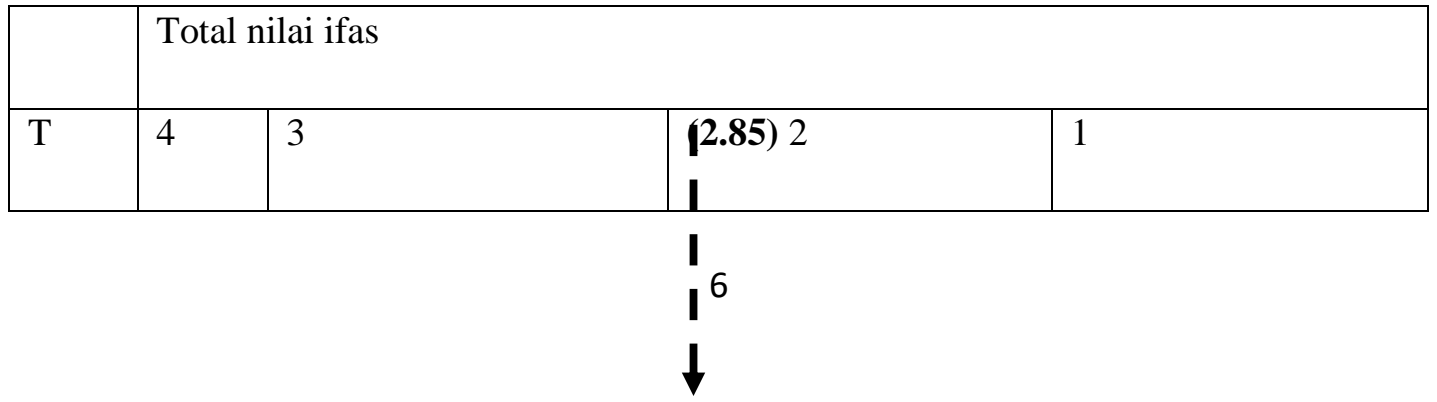




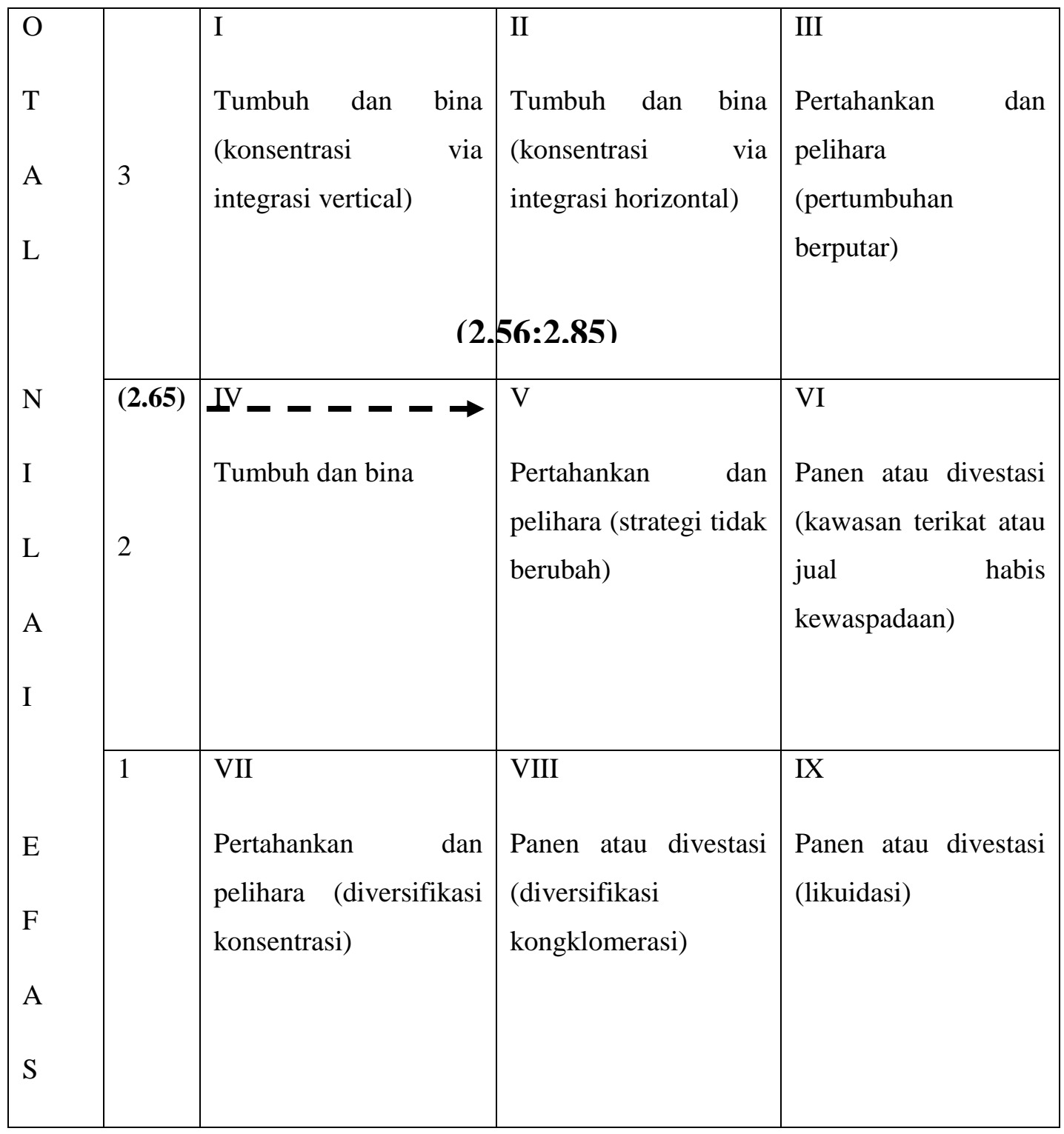

\section{Pilihan Strategi}

1. Strategi $\mathrm{S}-\mathrm{O}$

a. Penguatan Batam sebagai destinasi urban tourism

Potensi kota Batam sebagai Kota Metropolitan dan Free Trade Zone dan Kawasan Ekonomi Khususserta fasilitas lengkap Kota Batam sebagai kota metropolitan serta dari aspek pasar wisatawan yang besar membuat Kota Batam mempunyai Potensi Wisata Urban
Tourism. Dalam mengusung teori ruban tourism, prinsip dasar yang harus digunakan diperoleh dari Art Wales Theory yang mencangkup idea, people dan place. Potensi daerah dibagi menjadi tiga bagian yaitu orangnya, tempatnya dan ide kreatifnya.

b. Pengembangan Batam sebagai creative city Potensi budaya kota Batam serta kemajuan teknologi industri membuat Industri kreatif 
Kota Batam berkembang pesat. Pengembangan creative city Kota Batam harus mencakup kedalam 15 subsektor industri kreatif di Indonesia yang berbasis $3 \mathrm{i}$ model (brand integrity, brand identity,brand image).

2. Strategi $\mathrm{S}-\mathrm{T}$

a. Penguatan nilai daya tarik wisata pada kota Batam

Perkembangan teknologi dan pariwisata membuat kebutuhan pasar wisatawan menjadi dinamis serta perkembangan pariwisata yang pesat di daerah membuat Kota Batam harus memperkuat nilai daya tarik agar pariwisata di kota Batam tetap sustain. Penguatan nilai daya tarik Batam berdasarkan potensi pariwisata yang ada adalah pengembangan wisata Kota Batam dengan mengusung creatif city Kota Batam yang mengangkat food, fashion, festivities dan historycal sebagai produk pariwisata utama.

b. Perluasan model promosi berdasarkan target market

Perkembangan teknologi dan pariwisata membuat kebutuhan pasar wisatawan menjadi dinamis. Untuk mempromosikan destinasi pariwisata diperlukan model promosi yang tepat. Model promosi tersebut berupa pemetaan dan pengelolaan promosi dengan pendekatan Destination Origin - Time (DOT), Branding Advertising - Selling (BAS) serta Paid Own - Social Media (POS).

3. Strategi $\mathrm{W}-\mathrm{O}$

a. Penguatan event kota Batam

Penguatan event Kota Batam merupakan salah satu pilihan strategi dimana posisi aktivitas event Kota Batam belum mencerminkan destinasi wisata Batam dan berkembangnya wisatawan baik dari dalam dan luar negeri. Dengan adanya event di kota Batam, maka akan mempengaruhi kunjungan wisatawan.

b. Pengembangan media promosi Kota Batam berbasis teknologi

Dengan adanya perkembangan teknologi dan pasar wisatawan, maka strategi pengembangan media promosi berbasis teknologi perlu dilakukan di Kota Batam. Pengembangan media ini diharapkan akan memperluas segmen pasar yang nantinya dapat meraih target kunjungan wisatawan ke Kota Batam

4. Strategi $\mathrm{W}-\mathrm{T}$

a. Pengembangan model promosi kota Batam sebagai kota wisata

Perkembangan pariwisata di daerah membuat stakeholder pariwisata kota Batam harus kreatif dalam mengembangkan alat promosi yang efektif. Salah satu cara kreatif adalah dengan pengembangan model promosi menarik yang dikhususkan pada Tagline. Tagline yang menarik dapat mempengaruhi kunjungan wisatawan. Tagline yang ditawarkan peneliti adalah "Lovable Batam". Bentuk Love adalah representatif dari Tagline Wonderful Kepri dengan harapan semua yang berada di Kota Batam dapat menjadi potensi kecintaan wisatawan.

b. Pengelompokan dan penguatan karakter event kota Batam

Event merupakan komponen penting dalam pariwisata kota Batam. Untuk itu perlu diadakan inventarisasi dan penguatan karakter event kota Batam sehingga dapat merepresentasikan Kota Batam dan pada akhirnya dapat menarik angka kunjungan wisatawan yang berkunjung ke Kota Batam.

\section{SIMPULAN DAN SARAN}


Skor dari Matrik IFAS Wisata MICE Batam diperoleh dari hasil rata-rata pembobotan masing-masing indikator internal yang dikalikan dengan hasil rata-rata rating masing-masing indikator internal, maka didapat lah skor untuk masing-masing indikator internal. Setelah itu skor dari seluruh indikator-indikator internal harus dijumlahkan dengan cara menjumlah kanskor dari indicator pertama sampai dengan indicator terakhir untuk memperoleh hasil skor lingkungan internal. Hasil skor dari matrik IFAS pada adalah 2.65.

Skor dari matrik EFAS wisata MICE Batam diperoleh dari hasil rata-rata pembobotan masing-masingi ndikator eksternal yang dikalikan dengan hasil rata-rata rating masingmasing indicator eksternal, maka didapatlah skor untuk masing-masing indicator eksternal. Setelah itu skor dari seluruh indikator-indikator eksternal harus dijumlahkan dengan cara menjumlahkan skor dari indicator pertama sampai dengan indicator terakhir untuk memperoleh hasil skor lingkungan eksternal. Hasil skor dari matrik EFAS adalah 2.85.

\section{Saran}

1. PenguatanKota Batam sebagai destinasi urban tourism.

2. PengembanganBatamsebagaicreative city

3. Perluasan model promosiberdasarkan target market

4. Penguatan dan pengelompokan event kota Batam

\section{DAFTAR PUSTAKA}

Brandt, 2000 Brandt, D. Randall. 2000. Attitude Does Matter, Marketing News Burke White Paper Series, Vol. 2.

Boone, Louis E. Kurtz, David L. 2008. Pengantar Bisnis Kontemporer, buku 1. Jakarta: Salemba Empat.
Cooper et. al (1993) Cooper, Criss. Jhon Fletcher, David Gilbert and Stephen Wanhill. 1993.1995.Tourism Principles and Practice

E.B. Taylor (1871) Taylor, E.B (1958/1871) Primitive Culture : Researches in the Development of Mythologi, Religion, art and Custom, Gloucester, MA.

David, Fred. 2009. Strategic Management: Manajemen Strategis Konsep. Jakarta: Salemba Empat

Dyah Marganingrum. 2007. Tinjauan Karakteristik Wilayah Pantai Utara dan Selatan Jawa Barat dalam Rangka Pengelolaan Kawasan Pesisir Terpadu. Sumber Daya Air di Wilayah Pesisir dan Pulau-Pulau Kecil di Indonesia. 62-63

Gamal Suwantoro. 2004. Dasar-Dasar Pariwisata. Yogyakarta: Andi Offset

Hani S. Handayawati, et al. 2010. Potensi Wisata Alam Bahari. PM PSLP PPSU

Kesrul, M., 2004. Meeting Incentive Trip, Conference and Exhibition, Graha Ilmu, Jakarta.

Lembaga Ilmu Pengetahuan Indonesia. 2007. Sumber Daya Air di Wilayah Pesisir dan Pulau-Pulau Kecil di Indonesia. Jakarta: LIPI Press

Lexy J. Moleong. 2010. Metodologi Penelitian Kualitatif. Bandung: PT Remaja Rosdakarya

Masyhudzulhak Djamil. 2011. Pengelolaan Sumber Daya Wilayah Pesisir Dalam 
Perspektif Otonomi Daerah (Tinjauan Kota Bengkulu dan Kabupaten Bengkulu Selatan. Proceeding Book Simposium Nasional Ilmu Administrasi Negara Untuk Indonesia. 331-339

Muhammad Idrus. 2009. Metode Penelitian Ilmu Sosial. Jakarta: Penerbit Erlangga

Sofian Efendi. 2010. Reformasi Tata Kepemerintahan: Menyiapkan Aparatur Negara Untuk Mendukung Demokratisasi Politik dan Ekonomi Terbuka. Yogyakarta: Gajah Mada University Press
Mill, Robert, dan Morrison. 1985. The Tourism System.NewJarsley:Prentice hall International

Mc. Intosh, Goeldner dan Richie (1995) McIntosh, Goelder and Rithchin. 2004. World Tourism Organizatio. TourismBarometer. Madrid: WTO

Nasution, S. 2002. Metode Penelitian Naturalistik-Kualitatif. Bandung: Tarsito 